\title{
COMPUTER SIMULATION OF THE 7.62mm TT PISTOL EXTERNAL BALLISTICS USING TWO DIFFERENT AIR RESISTANCE LAWS
}

\author{
Vadim L. Khaikov \\ independent researcher, Krasnodar, Russian Federation, \\ e-mail: wadimhaikow@inbox.ru, \\ ORCIDiD: Dhttp://orcid.org/0000-0003-1433-3562
}

DOI: 10.5937/vojtehg66-16534; https://doi.org/10.5937/vojtehg66-16534

FIELD: Mechanics - Ballistics

ARTICLE TYPE: Original Scientific Paper

ARTICLE LANGUAGE: English

Abstract:

A description of a pistol (rifle) cartridge often involves two ballistic coefficients that characterize its ballistic qualities with respect to various air resistance laws (ARLs). How close are the obtained ballistic trajectories with varied $A R L$ specifications and what are the differences between them? How to evaluate ballistics if the ARLs are to be expressed in various mathematical forms? In this paper, the evaluation of external ballistics trajectories is given for two ARLs (the law brought in 1943 and the Siacci law). All the obtained results relate to the TT pistol with $7.62 \times 25 \mathrm{~mm}$ Tokarev cartridge.The paper also presents the answer to the question: how to calculate the ballistic trajectory if the ARL is expressed as a rational function, piecewise function or spline. For the $1943 A R L$, a graphical interpretation of the function $C d(i, v)$ in the form of a surface is shown. This paper shows that, due to the selection of ballistic coefficients, it is possible to obtain sufficiently similar form of ballistic trajectories. A method of graphical comparison of external ballistic parameters is presented as well as the mathematical tools for quantitative analysis of a shape of ballistic curves. The difference between the two trajectories is proposed to be estimated using a relative error in regard to a selected ballistic parameter. Computer simulation considered for the 1943 and Siacci ARLs for the $7.62 \times 25 \mathrm{~mm}$ Tokarev cartridge indicates that the profiles of the function of instantaneous projectile velocity vs time of flight (TOF) had the greatest non-coincidence in relation to other ballistic parameters (e.g. horizontal range, height of the trajectory, etc.) The obtained maximum of the relative error was $0.8 \%$. Its magnitude localizes at the point of impact.

Key words: computer simulation, external ballistics, TT pistol, air resistance law, drag function, the 1943 year law, bullet trajectory, spline, Mathcad. 
There are no dangerous weapons;

there are only dangerous men.

Robert A. Heinlein

\section{Introduction}

For one projectil type (bullet) that has equal initial conditions $\left(x_{0}, y_{0}\right.$, $\left.\theta_{0}, v_{0}\right)$, but its motion is characterized by two different ARLs, it is possible to calculate so-called «twins-trajectories». These are two trajectories with a practically identical form, but due to differences in ARLs descriptions, they have different values of the ballistic coefficients $C$. Errors related to inequality of such trajectories are usually not reported and it's completely unclear which of the external ballistic parameters $x, y$, $\theta, v$ for each of «twins-trajectories» has the greatest inconsistency.

In Europe and in the countries of North and South America, external ballistics of small arms projectiles is generally based on the use of wellknown G1/G7 air drag models; however, ARLs like the 1943 year law and the Siacci law are often used in the Commonwealth of Independent States or in countries - former members of the Warsaw Pact (or in countries that had in the past a military-technical cooperation with that defense treaty). One of the objectives of this article is to show how to carry out a ballistic simulation by using the 1943 and Siacci ARLs with various forms of their mathematical expressions. The second task is to present equality or inequality of the ballistic curves obtained as a result of the estimation process. For reducing the computer simulation (calculation) time, we will use the Mathcad 15 computer algebra system.

From the point of view of external ballistics, it is interesting to estimate the ballistics of one of well-known pistols, for instance, of the $7.62 \mathrm{~mm}$ Tokarev-TT ${ }^{1}$ pistol using two previously mentioned ARLs. It is known that pistols based on the TT construction were produced in many countries and the $7.62 \times 25$ cartridge is widespread.

In the scientific article (Bogdanovich, 2012, p.42) one can find «... one of the best pistols based on the $7.62 \mathrm{~mm}$ TT design was certainly the M57. This gun was constructed in Yugoslavia, at the «Zastava» plant and produced by Serbian "Zastava Arms» for export to various countries, including Europe and America». The arms plant «Crvena Zastava» (Kragujevac) began to produce the pistol-predecessor of the M57, namely the M54, in 1954 and at the same time the ammunition factory «Prvi Partizan» (Užice) launched a serial production of the

1 7.62mm Tokarev self-loading pistol model TT 1930 (TT-30) / TT 1933 (TT-33). The abbreviation «TT» means Tula-Tokarev. 
$7.62 \times 25 \mathrm{~mm}$ Tokarev cartridges. In addition, it should be said that the TT pistol and its upgrades were manufactured in PRC (Type 51 \& Type 54), in Hungary (M48, Tokagypt 58 with cartridge 9x19mm Para), in Romania (TTC), in DPR Korea (Type 68) and in other countries.

Ballistic and technical data. Table 1 shows the necessary technical specifications of TT-33, M54, and M57 pistols, important for evaluating their ballistics.

Table 1 - Technical specifications of TT-33, M54, and M57 pistols

Таблица 1 - Технические характеристики пистолетов TT-33, M54, M57

Табела 1 - Техничке карактеристике пиштоља TT-33, M54 и M57

\begin{tabular}{|c|c|c|c|c|}
\hline \multirow{2}{*}{ №/№ } & \multirow{2}{*}{ Specifications } & \multirow{2}{*}{ Units } & \multicolumn{2}{|c|}{ Model of pistols } \\
\hline & & & TT-33, M54 & M57 \\
\hline 1 & Chambering & $\mathrm{mm}$ & $7.62 \times 25 \mathrm{TT}$ & $7.62 \times 25 \mathrm{TT}$ \\
\hline 2 & Fire modes & - & $\begin{array}{l}\text { Semi-Auto, } \\
\text { Single Action }\end{array}$ & $\begin{array}{l}\text { Semi-Auto, } \\
\text { Single Action }\end{array}$ \\
\hline 3 & Bullet weight & $g$ & $5.49-5.52$ & $5.49-5.52$ \\
\hline 4 & Bullet length & $\mathrm{mm}$ & $14^{2}$ & - \\
\hline 5 & Bore length & $\mathrm{mm}$ & 116 & 116 \\
\hline 6 & Rifling length & $\mathrm{mm}$ & 100 & - \\
\hline 7 & Number of grooves & - & $4 \mathrm{RH}$ & $4 \mathrm{RH}$ \\
\hline 8 & Number of lands & - & 4 & 4 \\
\hline \multirow{4}{*}{9} & \multirow{4}{*}{ Twist rate } & $\mathrm{mm}$ per turn & 240 & 240 \\
\hline & & inch per turn & 9.45 & 9.45 \\
\hline & & $\mathrm{clb}^{3}$ per turn & 31.496 & 31.496 \\
\hline & & $1 "$ & $5^{\circ} 41^{\prime} 45^{\prime \prime}$ & $5^{\circ} 41^{\prime} 45^{\prime \prime}$ \\
\hline 10 & Initial velocity & $\mathrm{mps}$ & 420 & 440 \\
\hline 11 & Bullet muzzle energy & Joule & 485.54 & 532.88 \\
\hline 12 & Bullet spin rate & $\mathrm{rps}$ & 1750 & $1750-1896$ \\
\hline 13 & Effective firing range & $\mathrm{m}$ & 50 & 50 \\
\hline 14 & Bullet flight range & $\mathrm{m}$ & $800-1000$ & 1640 \\
\hline 15 & Sight radius & $\mathrm{mm}$ & 156 & 158 \\
\hline 16 & Max mean pressure & $\mathrm{kg} / \mathrm{cm}^{2}$ & 2234 & - \\
\hline 17 & Practical rate of fire & rpm & 30 & - \\
\hline 18 & Precision (range: $50 \mathrm{~m}$ ) & $\mathrm{m}$ & 0.25 & - \\
\hline
\end{tabular}

Sources: (Bogdanovich, 2012, p.49) and author's estimations

\footnotetext{
2 for ordinary bullet P-type (cyrillic: пуля «П» - простая)

${ }^{3} \mathrm{clb}$ - bullet caliber
} 
Based on (http://popgun.ru,nd), the curves of pressure and bullet velocity vs rifling length (time) for the $7.62 \mathrm{~mm}$ bullet of the TT-33 pistol in a logarithmic scale were built (Figure 1). The main advantage of the logarithmic scale is that it allows "to stretch the graph» in the direction to the origin (to the point « $0 \mathrm{~mm}$ » by using the argument bore length and to the point " 0 seconds» by using the argument time). The fragment $a$ of Figure 1 shows the change of the projectile velocity in the barrel; the fragment $b$ indicates the internal ballistic curve of the mean pressure in the barrel.
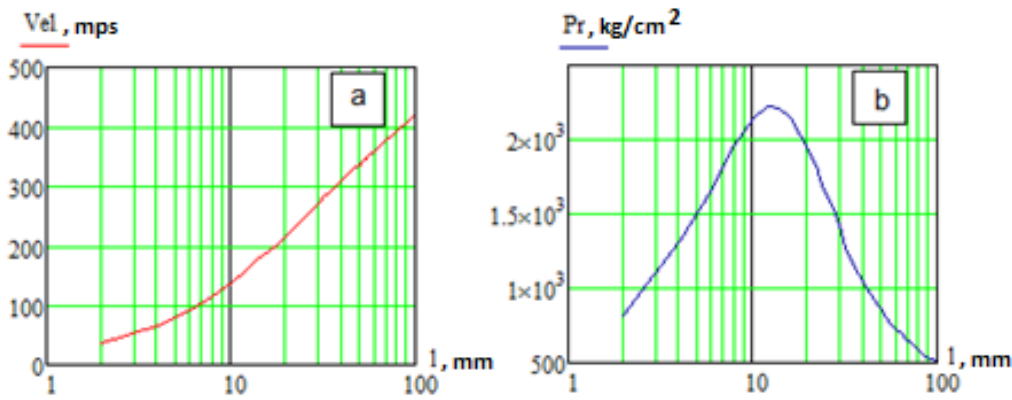

Figure 1 - Internal ballistic curves of the TT pistol (argument - bore length)

Puс. 1 - Внутрибаллистические кривые пистолета ТT (аргумент - длина ствола пистолета)

Слика 1 - Унутрашње балистичке криве пиштоља ТT (аргумент - дужина цеви)
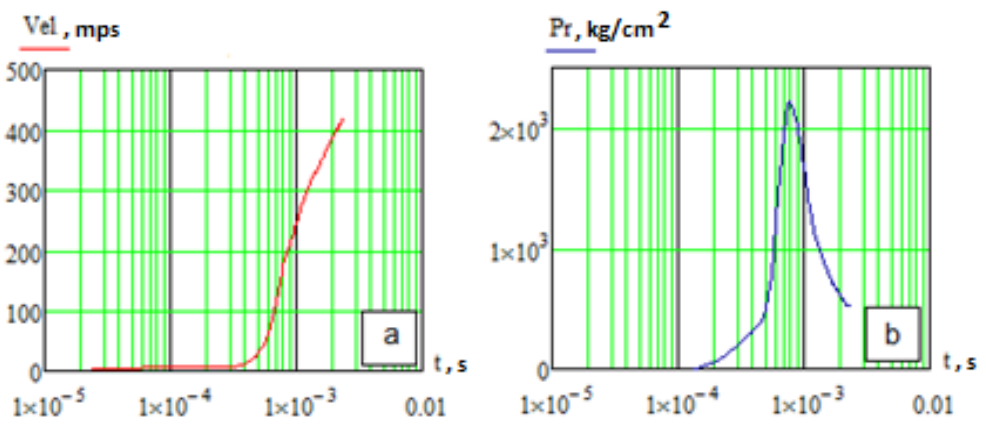

Figure 2 - Internal ballistic curves of the TT pistol (argument time): a - the projectile velocity in the barrel; $b$-internal ballistic curve of the mean pressure in the barrel. Puс. 2 - Внутрибаллистические кривые пистолета ТT (аргумент - время): $a$ - скорость снаряда в стволе; $b$ - внутрибаллистическая кривая среднего давления в стволе.

Слика 2 - Унутрашње балистичке криве питоља ТT (аргумент - време): а) брзина пројектила унутар цеви, б) унутрашња балистичка крива средње вредности притиска унутар цеви. 
The dependences of the bullet velocity and the mean pressure as a function of time are also obtained (Figure 2). The graphs show that the bullet initial velocity is $420 \mathrm{mps}$, and the mean pressure maximum is $2234 \mathrm{~kg} / \mathrm{cm}^{2}$. The duration of the intraballistic cycle for the TT-33 pistol is approximately 2.5 milliseconds.

The mathematical model. Longitudinal motion of a pistol bullet in the Earth's atmosphere can be described by the system of ODEs with an independent argument TOF $(t)$ (Regodić, 2006). This type of mathematical expression belongs to the Point-mass Trajectory Model type:

$$
\left\{\begin{array}{l}
\frac{d v}{d t}=-g \sin (\theta)-\frac{\rho v^{2}}{2 m} A C_{d} \\
\frac{d \theta}{d t}=-\frac{g \cos (\theta)}{v} \\
\frac{d x}{d t}=v \cos (\theta) \\
\frac{d y}{d t}=v \sin (\theta)
\end{array}\right.
$$

where $v$ - the instantaneous bullet velocity, $\mathrm{m} / \mathrm{s} ; t$ - the time of flight, $\mathrm{s}$; $g$ - the acceleration of gravity at the point of departure, $\mathrm{m} / \mathrm{s} 2 ; \theta$ - the angle of the velocity vector relative to the base of a trajectory, radian; $\rho$ - the air density, $\mathrm{kg} / \mathrm{m} 3 ; m$ - the mass of projectile, $\mathrm{kg} ; A$ - the cross section of the projectile, $\mathrm{m} 2 ; C_{d}-$ a drag function, dimensionless; $x$ - the abscissa (horizontal range) of the trajectory, $\mathrm{m} ; y$ - the ordinate of the trajectory, $\mathrm{m}$.

The density of the air $\rho$ as a function of the projectile flying altitude $y$ :

$$
\rho=\rho_{0^{*}} H(y),
$$

where $\rho_{0}$ is the density of the air at the ground-level; $H(y)$ is the function which indicates a relative variation of the air density with respect to the altitude $y$.

Using the standard ARLs $C_{d s t}$ and the coefficient $i$, it is possible to transform the first ODE of system (1):

$$
\frac{d v}{d t}=-g \sin (\theta)-\frac{\rho v^{2}}{2 m} A i C_{d s t}
$$


where $i$ - coefficient taking into account a shape of (launched) bullet (socalled form coefficient ${ }^{4}$ ), dimensionless; $C_{d s t}$ - the standard air drag function, dimensionless.

Coefficients $i$ and ARL models. According to collected sources, the $i$ coefficients for the $7.62 \mathrm{~mm}$ pistol bullet and $9 \mathrm{~mm}$ bullets are shown in Table 2.

Table 2 - Values of the coefficient $i$ for pistol bullets

Таблица 2 - Значение коэффрициента $i$ для пистолетных пуль Табела 2 - Вредности коефицијента $i$ за зрна пиштоља

\begin{tabular}{|c|c|c|c|c|c|}
\hline \multirow{2}{*}{$\begin{array}{l}\text { Type of cartridge and } \\
\text { bullet }\end{array}$} & \multirow{2}{*}{$\begin{array}{l}\text { Initial } \\
\text { velocity } \\
v_{0}, \mathrm{mps}\end{array}$} & \multirow{2}{*}{$\begin{array}{l}\text { Bullet } \\
\text { weight, } \\
\text { g }\end{array}$} & \multicolumn{2}{|l|}{$\mathrm{ARL}$} & \multirow[b]{2}{*}{ Source } \\
\hline & & & 1943 & Siacci & \\
\hline $7.62 \times 25 \mathrm{~mm}$ Tokarev & 420 & 5.505 & 1.35 & 0.75 & $\begin{array}{l}\text { (Kirillov, } \\
\text { 1963, p.68) }\end{array}$ \\
\hline $9 \times 18 \mathrm{~mm}$ Makarov ${ }^{5}$ & 315 & 6.1 & - & 0.98 & $\begin{array}{l}\text { (Vodorezov, } \\
2017, \text { p.166) }\end{array}$ \\
\hline 9x19mm Luger (FMJ) & 376 & 7.4 & 1.526 & 0.77 & $\begin{array}{l}\text { (https:// } \\
\text { forum.guns.ru, nd) }\end{array}$ \\
\hline 9x19mm Luger (HP) & 308 & 9.4 & 1.509 & 0.755 & $\begin{array}{l}\text { (https:// } \\
\text { forum.guns.ru, nd) }\end{array}$ \\
\hline
\end{tabular}

A comparison of the values of the coefficients $i$ for $7.62 \times 25 \mathrm{~mm}$ Tokarev indicates that its value for the ARL of Siacci is 1.8 times lower than $i$ for the ARL of the 1943 year.

The 1943 law drag model is often used to describe ballistics of pistol bullets, for example, for 9mm Para cartridge (Jankových, 2012, p.29) or for $9 \mathrm{~mm}$ Luger (https://guns.ru, nd).

The coefficient $i$ can be calculated by the following formula (Faraponov et al, 2017, p.35)

$$
i=\frac{m}{1000 d^{2}} C
$$

\footnotetext{
${ }^{4}$ In the book of Semikolenov, Bondarenko \& Krasner «Principles of small unit weapons firing» (Semikolenov et al, 1971) on the p.67 $i$ is named as "the coefficient for the projectile shape".

${ }^{5}$ The files for software Exterior Ballistics 2.5 (http://ballistics.eu/index.html, nd) contain data for the cartridge $9 \times 18$ Makarov with FMJ bullet $\left(6.22 \mathrm{~g}\right.$.) and $V_{0}=346 \mathrm{mps}$ : $\mathrm{BC}=0.1$; drag model G1.
} 
where $i$ - the form coefficient, dimensionless; $m$ - the mass of the projectile/bullet, $\mathrm{kg} ; d$ - the caliber of the projectile/bullet, $\mathrm{m} ; C-$ the ballistic coefficient of the projectile, $\mathrm{m}^{2} / \mathrm{kg}$.

"Although the coefficient $i$ is usually regarded as a constant value, as it can be seen from the expression

$$
i=C_{d}\left(\frac{v}{a}\right)\left(C_{d_{s t}}\left(\frac{v}{a}\right)\right)^{-1},
$$

it, strictly speaking, depends on the instantaneous projectile velocity.

Therefore, using a projectile (bullet) of the same shape in different ranges of velocity, we can get some discrepancies in the numerical values of the coefficient $i$. For the same reason, the value of the coefficient $i$ for the same projectile and for the same initial velocity depends on the angle of departure (AOD). This is explained by the fact that changing of AOD gives a change in the velocity range along the trajectory» (Shapiro, 1946, p.58).

For example, the relationship between the 1943 year ARL and the Siacci ARL in the range of up to $5 M$ is shown in Figure 3 (Khaikov, 2017, p.83). The coefficient $i$ as a function of the Mach number $(M)$ is complicated, i.e. it is not monotonous. The graph of the $i(M)$ function has two local minimums and one local maximum (see the right graphics window). However, $i(M)$ can be characterized by some average value, which is equal to half of the area under the $i(M)$ function graph.
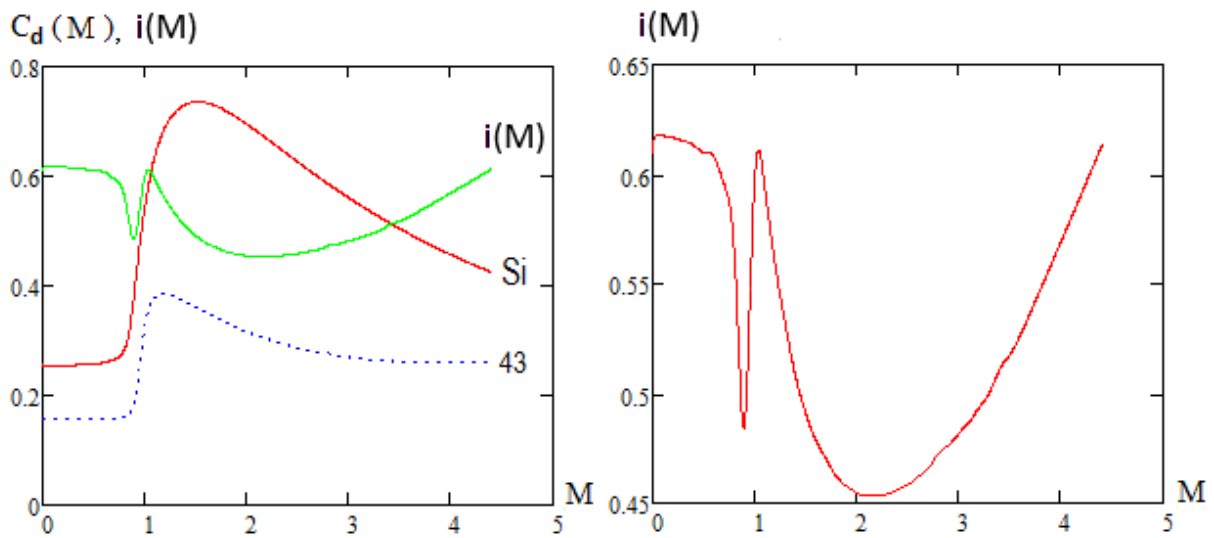

Figure 3 - Relationship between the two ARLs

Puc. 3 - Отношение двух законов сопротивления воздуха

Слика 3 - Однос између два закона отпора ваздуха 
If $i(M)$ and the coefficient $i$ are considered as a constant, then the function $C_{d}(i, v)$ can be represented as a surface (Figure 4$)$. For $i=1$, we have a standard function $C_{d_{s t}}\left(\frac{v}{a}\right)$, which is a section of the surface (orange line). For $i \neq 1$, the individual function $C_{d}$, such as a purple line $(i>1)$.

Using the value of the coefficient $i$, the caliber of the bullet, its mass, it is possible to calculate the ballistic coefficient $C$ (Germershausen, 1982, p.159)

$$
C=1000 \cdot i \cdot d^{2} \cdot q^{-1}
$$

In this case, we obtain the function $C_{d}(C, v)$.

However, there is an alternative formula for calculating the ballistic coefficient (BC) $C=m \cdot\left(d^{2} \cdot i\right)^{-1}$. In order to avoid misunderstanding, it is necessary to indicate a type of a calculation formula for ballistic coefficient determination.

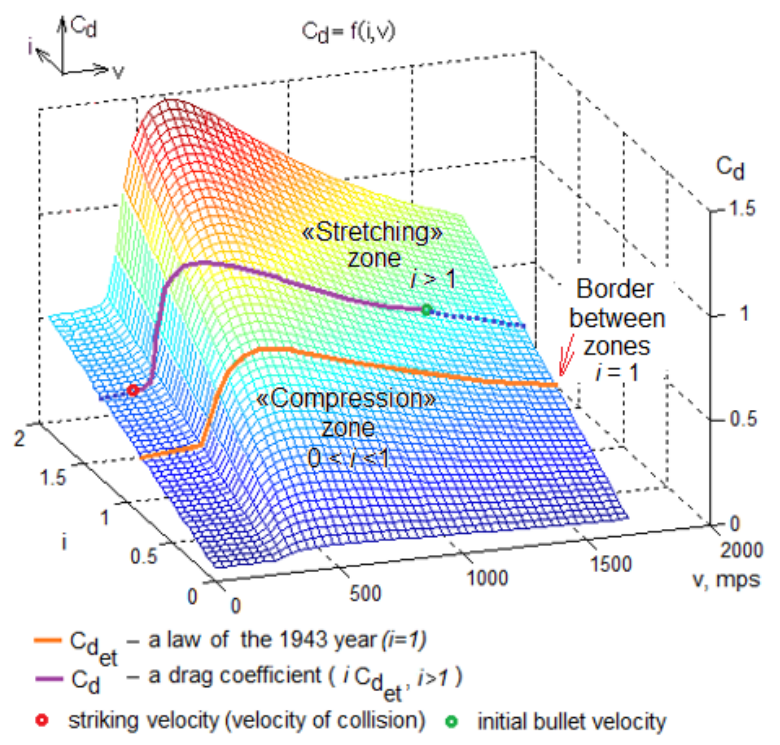

Figure 4 - The function $C_{d}(i, v)$ in the form of a surface Puc. 4 - Функция $C_{d}(i, v)$ в форме поверхности Слика 4 - Функција $C_{d}(i, v)$ у облику површине 
So, if $i(v)=$ const, then the surface (Figure 4) shows all possible individual drag-functions which depend on $i$. When the coefficient $i$ is multiplied by $C_{d_{s t}}\left(\frac{v}{a}\right)$, a linear transformation of the function takes place: for $i>1$, the graph is stretched from the abscissa axis $i$ times; for $0<i<1$ this is the compression of the graph to the $x$-axis by $1 / i$ times.

Therefore, the standard function $C_{d_{s t}}\left(\frac{v}{a}\right)$ is the boundary between the "compression» and «stretching» zones of the $C_{d}(i, v)$ surface. Since any ballistic trajectory has the initial and striking velocity of the projectile, due to the surfaces $C_{d}(i, v)$ or $C_{d}(C, v)$ we can show the range of the coefficient $C_{d}$ that is necessary for flight path calculations.

Different forms of ARL expressions. ARLs or function can be described as: a classical analytical function; a piecewise function and a spline function. The spline function can be regarded as a special kind of the piecewise function.

Analytical forms for the ARL of the 1943 year. In view of the fact that the summit of the bullet trajectory in air for pistol external ballistics is not a large value, the speed of sound can be considered as a constant value. That is in the formula

$$
M=v / a,
$$

where $v$ - instantaneous bullet velocity; $a$ - local speed of sound (constant).

The ARL of the 1943 year is a table-valued function that can be found in (Konovalov \& Nikolayev, 1979, p.191) and approximated using a rational function:

$$
C_{d 43_{R F}}\left(\frac{v}{a}\right)=P\left(\frac{v}{a}\right)\left(Q\left(\frac{v}{a}\right)\right)^{-1} .
$$

The conducted investigation of possible approximation forms for the ARL of the 1943 year led to the following rational function (Khaikov, 2017, p.85) $(0.1 \leq v / a \leq 4)$ : 


$$
\begin{aligned}
C_{d 43_{R F}}\left(\frac{v}{a}\right)=\frac{1.378212-7.1379605\left(\frac{v}{a}\right)+15.498681\left(\frac{v}{a}\right)^{2}}{8.7777403-45.498974\left(\frac{v}{a}\right)+99.290858\left(\frac{v}{a}\right)^{2}} . . \\
. . \frac{-17.778376\left(\frac{v}{a}\right)^{3}+10.605229\left(\frac{v}{a}\right)^{4}-1.7807148\left(\frac{v}{a}\right)^{5}}{-17.778376\left(\frac{v}{a}\right)^{3}+74.91108\left(\frac{v}{a}\right)^{4}-21.331814\left(\frac{v}{a}\right)^{5} .} \\
. .1 .6876336\left(\frac{v}{a}\right)^{6}+1.164362\left(\frac{v}{a}\right)^{7}-0.2873904\left(\frac{v}{a}\right)^{8} \\
-3.0222138\left(\frac{v}{a}\right)^{6}+4.0786158\left(\frac{v}{a}\right)^{7}-1.0962723\left(\frac{v}{a}\right)^{8} . \\
+0.02598584\left(\frac{v}{a}\right)^{9} \\
. .0 .1012291\left(\frac{v}{a}\right)^{9}
\end{aligned}
$$

Another form of mathematical expression for the ARL of the 1943 year is a sum of rational and exponential functions (R\&EF) (Kozlitin \& Omelyanov, 2016, p.29):

$$
C_{d 43_{R \& E F}}\left(\frac{v}{a}\right)=\frac{P\left(\frac{v}{a}\right)}{Q\left(\frac{v}{a}\right)}+\frac{b_{0}}{1+\exp \left(b_{1}\left(\frac{v}{a}\right)+b_{2}\right)}+d_{0}
$$

It should be noted that the rational function (i.e. first summand) uses only even powers (from 0 to 12 , namely $0,2,4, . .10,12$ ). R\&EF is expressed by the following formula $(0.1 \leq v / a \leq 4.0)$ with eighteen empirical coefficients 


$$
\begin{aligned}
& C_{d 43_{\text {R\&FF }}}\left(\frac{v}{a}\right)=\frac{-1.9382+4.2980\left(\frac{v}{a}\right)^{2}+0.3207\left(\frac{v}{a}\right)^{4}}{296.9213-853.9492\left(\frac{v}{a}\right)^{2}+985.5873\left(\frac{v}{a}\right)^{4}} . . \\
& . . \frac{-9.4610\left(\frac{v}{a}\right)^{6}+8.9342\left(\frac{v}{a}\right)^{8}-0.9476\left(\frac{v}{a}\right)^{10}}{-580.8643\left(\frac{v}{a}\right)^{6}+178.6690\left(\frac{v}{a}\right)^{8}-15.4071\left(\frac{v}{a}\right)^{10}} . . \\
& . . \frac{+0.0525\left(\frac{v}{a}\right)^{12}}{+1.0000\left(\frac{v}{a}\right)^{12}}+\frac{0.0531}{1+\exp \left(-90.5063\left(\frac{v}{a}\right)+85.5194\right)}+0.1639
\end{aligned}
$$

The research carried out in (Khaikov, 2017, p.88) showed that the matrixes $\mathbf{P}, \mathbf{Q}, \mathbf{B}$ and $\mathbf{D}$ in formula (3) may have different coefficients. For example, the matrices $\mathbf{P}_{\mathbf{1}}, \mathbf{Q}_{\mathbf{1}}, \mathbf{B}_{\mathbf{1}}$ and $\mathbf{D}_{\mathbf{1}}$ with alternative coefficients are presented below:

$$
\begin{gathered}
\mathbf{P}_{1}=\left(\begin{array}{l}
10.189924313 \\
-32.2497749054 \\
42.0499139169 \\
-28.8388279297 \\
9.989953385 \\
-0.6976279168 \\
0.0403773785
\end{array}\right) \mathbf{Q}_{1}=\left(\begin{array}{l}
-0.9050248435 \\
2.8653174742 \\
-3.7411757325 \\
2.5742663163 \\
-0.8961295841 \\
0.0627439736 \\
-0.0036275618
\end{array}\right) \\
\mathbf{B}_{1}=\left(\begin{array}{l}
0.06274397 \\
16.399062 \\
57.358636
\end{array}\right) \mathbf{D}_{1}=(11.416713)
\end{gathered}
$$


The ARL of the 1943 year can be expressed as a piecewise function (5) (Khaikov, 2017, p.80) consisting of 9 unequal intervals. This function is a modification of the formula from (Konovalov\& Nikolayev, 1979, p.84) in which one more interval is added

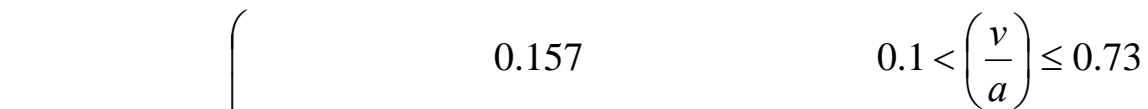

$$
\begin{aligned}
& 0.033\left(\frac{v}{a}\right)+0.133 \quad 0.73<\left(\frac{v}{a}\right)<0.82 \\
& 3.9\left(\frac{v}{a}\right)^{2}-6.4194\left(\frac{v}{a}\right)+2.8025831 \quad 0.82 \leq\left(\frac{v}{a}\right) \leq 0.91 \\
& 1.5\left(\frac{v}{a}\right)-1.176 \quad 0.91 \leq\left(\frac{v}{a}\right) \leq 1.00 \\
& C_{d 43_{P W F}}\left(\frac{v}{a}\right)=-1.6\left(\frac{v}{a}\right)^{2}+3.7632\left(\frac{v}{a}\right)-1.82876161 .00<\left(\frac{v}{a}\right) \leq 1.18 \\
& 0.384 \sin \left(1.85\left(\frac{v}{a}\right)^{-1}\right) \quad 1.18<\left(\frac{v}{a}\right)<1.62 \\
& 0.29\left(\frac{v}{a}\right)^{-1}+0.172 \quad 1.62 \leq\left(\frac{v}{a}\right)<3.06 \\
& -0.011\left(\frac{v}{a}\right)+0.301 \quad 3.06 \leq\left(\frac{v}{a}\right) \leq 3.53 \\
& 0.259 \\
& 3.53 \leq\left(\frac{v}{a}\right) \leq 4.0
\end{aligned}
$$

The «PWF» subscript denotes a piecewisefunction.

Analytical forms for ARL of Siacci. The F-curve for the Siacci law is written (Mori, 2013, p.41)

$$
F_{s i}(v)=0.2002 v-48.05 \sqrt{(0.1648 v-47.95)^{2}+9.6}+\frac{0.0442 v(v-300)}{371+\left(\frac{v}{200}\right)^{10}}
$$


Due to division by $4.74 \cdot 10^{-4} v^{2}$ we can transform the F-curve into the $C_{d}$ - type function (Shapiro, 1946, p.37)

$$
C_{d_{s i}}(v)=\frac{F_{s i}(v)}{4.74 \cdot 10^{-4} v^{2}}
$$

The ARL of Siacci as a table-valued function can be found in (Konovalov \& Nikolayev, 1979, p.191).

The technology of using spline functions is demonstrated in the appendix to this articleas well as in (Khaikov, 2018).

Different forms of the mathematical notations for ARLs of the 1943 year and Siacci law are combined in Table 3.

Table 3 - Forms of the mathematical notations for the ARLs of the 1943 year and Siacci law

Таблица 3 - Формы математических обозначений законов сопротивления воздуха 1943 года и Сиаччи

Табела 3 - Форме математичких појмова за законе отпора ваздуха из 1943. године и Sіассі-јевог закона

\begin{tabular}{|l|l|l|l|}
\hline \multirow{2}{*}{ ARL } & \multicolumn{2}{|l|}{ Analytic functions } & $\begin{array}{l}\text { Table-valued } \\
\text { function }\end{array}$ \\
\cline { 2 - 4 } & Classical analytic form & Piecewise form & $* 6$ \\
\hline 1943 & Formulas 2 -4 & Formula 5 & \\
\hline Siacci & Formulas 6,7 & - & $*$ \\
\hline
\end{tabular}

Mathcad programming code. The commented Mathcad-code is presented below. The characteristics for a pistol bullet are determined: caliber $(0.00762 \mathrm{~m}=7.62 \mathrm{~mm})$, weight $(0.0055 \mathrm{~kg})$ and a value of the $i$ coefficient (i_43) (according to the the chosen law):

$$
d:=0.00762 \quad q:=0.0055 \quad i_{-} 43:=1.35
$$

$6 *$ - source corresponds (Konovalov et al, 1979, p.191). 
An angle of departure (in radians) is calculated as a set of angular degrees, minutes and seconds:

$$
\begin{array}{cc}
\text { Gradus }:=0 \quad \text { Min }:=10 \quad \text { Sec }:=0 \\
\theta_{0}:=\frac{\pi}{180}\left(\text { Gradus }+\frac{\text { Min }}{60}+\frac{\text { Sec }}{3600}\right)=2.909 \cdot 10^{-3}
\end{array}
$$

At the point of departure, the value of the acceleration coefficient of gravity is determined as $9.18 \mathrm{~m} / \mathrm{s}^{2}$. Further, it is necessary to determine the time interval of integration: its boundaries and the total number of integration points:

$$
t_{\text {beg }}:=0 \quad t_{\text {end }}:=1.1 \quad n_{\text {points }}:=1000
$$

The initial conditions (for formula (1)) are determined as a matrixcolumn $y$, which will contain their known numerical values:

$$
y:=\left(\begin{array}{l}
y_{0}=v(0) \\
y_{1}=\theta(0) \\
y_{2}=x(0) \\
y_{3}=y(0)
\end{array}\right) .
$$

In view of the fact that the initial velocity of the $7.62 \mathrm{~mm}$ TT bullet is $420 \mathrm{~m} / \mathrm{s}$, the matrix-column $y$ will look like:

$$
y:=\left(\begin{array}{c}
420 \\
2.051 \times 10^{-3} \\
0 \\
0
\end{array}\right) .
$$


The matrix $D(t, y)$ has the form

$$
D(t, y):=\left[\begin{array}{c}
-g \cdot \sin \left(y_{1}\right)-\frac{\rho \cdot\left(y_{0}\right)^{2}}{2 \cdot m} \cdot A \cdot i_{-}-43 \cdot C d\left(\frac{y_{0}}{a}\right) \\
\frac{-g \cdot\left(\cos \left(y_{1}\right)\right)^{2}}{y_{0}} \\
y_{0} \cdot \cos \left(y_{1}\right) \\
y_{0} \cdot \sin \left(y_{1}\right)
\end{array}\right]
$$

The matrix-column $D(t, y)(8)$ is the right-hand part of the system of ODEs (1). It includes the following variables: the instantaneous projectile velocity $v-y_{0}$, the angle of inclination of the tangent $\theta-y_{1}$, the abscissa of the trajectory $x-y_{2}$; the ordinate of the trajectory $y-y_{3}$. In connection with the fact that $C_{d}$ in formulas (2), (3) or other presenta long and cumbersome expression, it is given in (8) only as a «short» notation.

If a calculation in the Mathcad system is implemented, then $C_{d}$ must be replaced by the complete mathematical expression. In this formula, the sign of $v$ (velocity) is replaced by $y_{0} . i_{-} 43-$ the form coefficient of the 1943 year law in the Mathcad program.

For example, the matrix-column $D(t, y)$ will have the form (for $C_{d}$ only three initial terms are given; the powers of $\frac{y_{0}}{a}$ are from 0 to 2). A Mathcad script for $D(t, y)$ is given below:

$$
D(t, y):=\left[\begin{array}{c}
-g \cdot \sin \left(y_{1}\right)-\frac{\rho \cdot\left(y_{0}\right)^{2}}{2 \cdot m} \cdot A \cdot i_{-} 43 \\
\frac{8.7777403-45.498974\left(\frac{y_{0}}{a}\right)+99.290858\left(\frac{y_{0}}{a}\right)^{2}+\ldots}{\frac{-g \cdot\left(\cos \left(y_{1}\right)\right)^{2}}{y_{0}}} \\
y_{0} \cdot \cos \left(y_{1}\right) \\
y_{0} \cdot \sin \left(y_{1}\right)
\end{array}\right]
$$


The complete Mathcad script of $C_{d 43_{R F}}\left(\frac{y_{0}}{a}\right)$ and $C_{d 43_{R \& E F}}\left(\frac{y_{0}}{a}\right)$ expressions is given in formulas (2) and (4). In order to use the piecewise function (5) for the calculation in Mathcad, we transform it to the form:

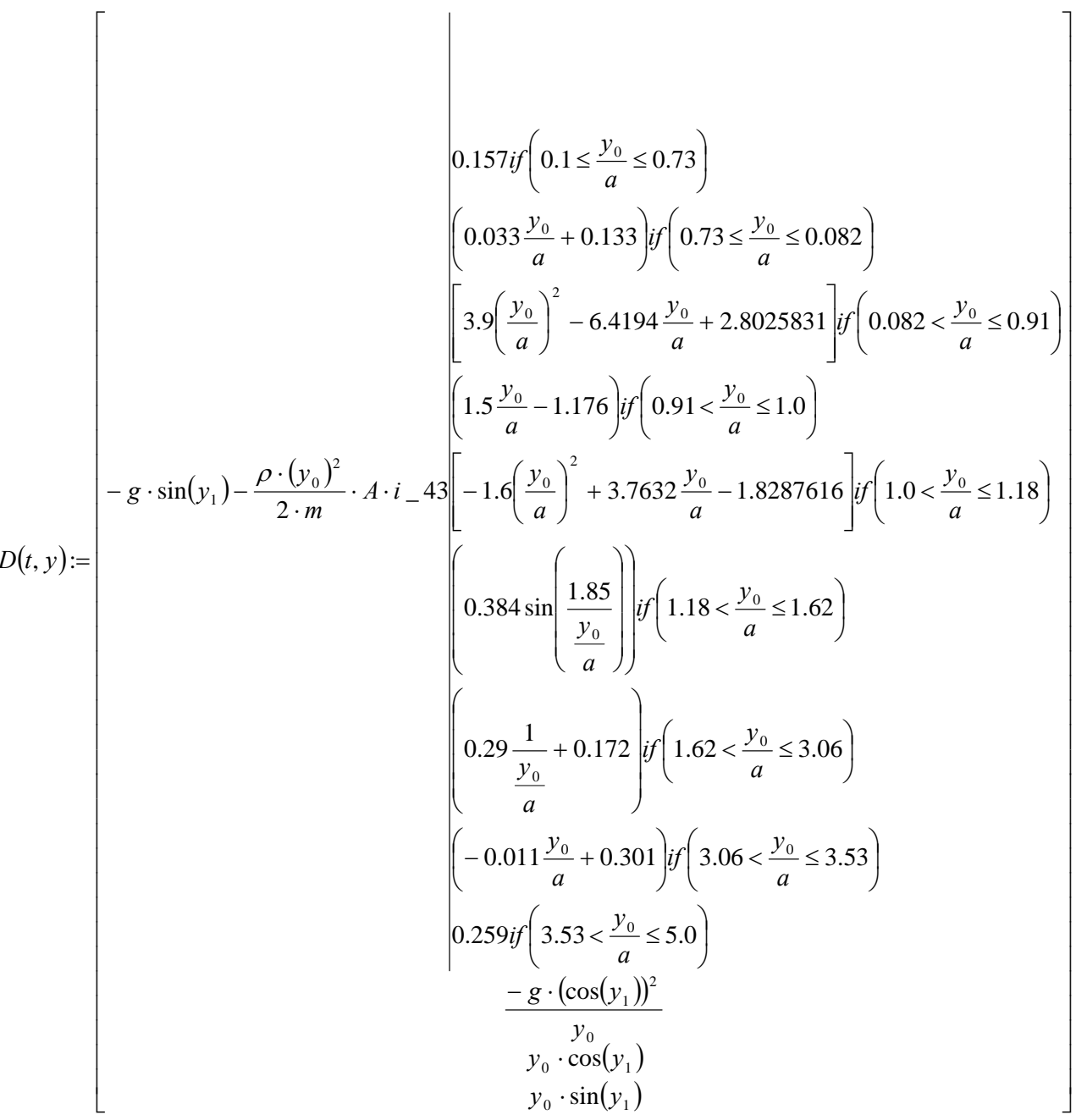


Below we give an example of the matrix $D(t, y)$ for the description of the ARL and the system of ODEs (1) by using the cubic spline. The import of the table-valued function of $A R L$ is carried out from an external file. Its can be the text «.txt» file or the Microsoft Excel «.xls» file ${ }^{7}$.

$$
D(t, y):=\left[\begin{array}{c}
-g \cdot \sin \left(y_{1}\right)-\frac{\rho \cdot\left(y_{0}\right)^{2}}{2 \cdot m} \cdot A \cdot i_{-} 43 \cdot \operatorname{interp}\left(\operatorname{cspline}\left(\text { vel, } C_{d}\right), \text { vel, } C_{d}, y_{0}\right) \\
\frac{-g \cdot\left(\cos \left(y_{1}\right)\right)^{2}}{y_{0}} \\
y_{0} \cdot \cos \left(y_{1}\right) \\
y_{0} \cdot \sin \left(y_{1}\right)
\end{array}\right]
$$

Alternatively, the data for the ARL may not be imported from the file, but be part of the $D(t, y)$ matrix. In this case, data are written in the form of row-matrices (separated for velocities and separately for $C_{d}$ data). Next, as in the previous example, we use cubic spline interpolation.

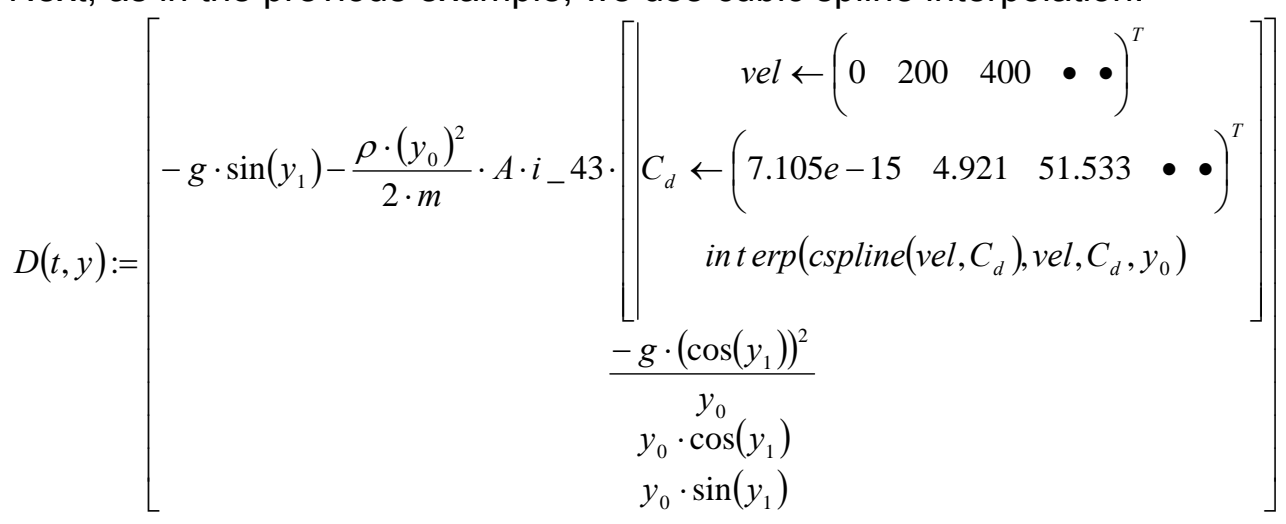

\footnotetext{
${ }^{7}$ Variables vel, Cd should be described as global variables. They are introduced to the matrix $D(t, y)$ using the «READFILE» Mathcad function.
} 
The solver-function rkfixed is implemented in the non-stiff fourth order Runge-Kutta numerical method with a fixed step. More information about the integration of ODEs in Mathcad can be found in (Khaikov, 2018, p.298).

Calculations. Calculations were performed for the ARL of the 1943 year for $4 C_{d}$-types (RF, R\&EF, piecewise, spline-function) and 2 types of the Ciacci ARL (analytical and spline-function). The variable Num Result is the matrix that contains the results of the numerical solution of (1). In this case, the matrix has the dimension of $5 \times 1001$ elements and contains 5005 numbers. Five columns of the Num_Result matrix are: independent argument TOF (t); and elements of the matrix $y$ (or D) namely $v, \theta, x, y .1001$ rows are the sum of 1 (initial condition) and $\mathrm{n}$ points. The first row of the matrix Num_Result includes $t(0), v(0), \theta(0)$, $x(0), y(0)$. The first column of the matrix Num_Result contains 1001 discrete TOF values: from $t_{\text {beg }}=t(0)$ to $t_{\text {end }}$. The 5 -by-1001 matrix from the second to fifth columns (in each of them) has 1001 values of the quantities $v, \theta, x, y$ respectively. This means that we have 1001 values of instantaneous velocity, 1001 values of $\theta, 1001$ values of $x$ and so on.

It was shown previously that for obtaining two trajectories with the same horizontal range but characterized by different ARLs, it is necessary to make selection of ballistic coefficients. This procedure allows obtaining sufficiently close forms of both ballistic trajectories. However, due to the fact that the bullet movement for each flight path is determined by the intrinsic $A R L$, then the bullet retardation process will not coincide with «twins-trajectories». For a comparison of dependencies between the elements of ODEs (1), the method developed in (Khaikov, 2018, p.281303) will be used below. The solution of system (1) is represented as a five-dimensional space. Each element of this $5 \mathrm{D}$-space is a function between the variables $(x, y, \theta, v)$ and the argument $(t)$, obtained as a result of numerical solution (1). The angle $\theta$ is calculated in angular minutes (or minute of angle (MOA). Since the solution of system (1) depends on the ballistic coefficient, it becomes possible to compare the same-named dependencies $\left(x_{1}, y_{1}, \theta_{1}, v_{1}, t_{1}\right),\left(x_{2}, y_{2}, \theta_{2}, v_{2}, t_{2}\right)$ obtained for different values of the coefficients $c_{1}$ and $c_{2}$. The entire set of relations between the variables and the independent argument of (1) is presented in Table 4. The order of the values $(x, y, \theta, v, t)$ location in the 5-by-1001 matrix Num_Result and in Table 4 is different. 
Table 4 - Structure of the relations for ODEs parameters (1) for two ARLs Таблица 4 - Структура соотношений параметров системы диффреренциальных уравнений (1) при различных законах сопротивления

Табела 4 - Структура односа параметара ОДЈ (1) за два закона отпора ваздуха

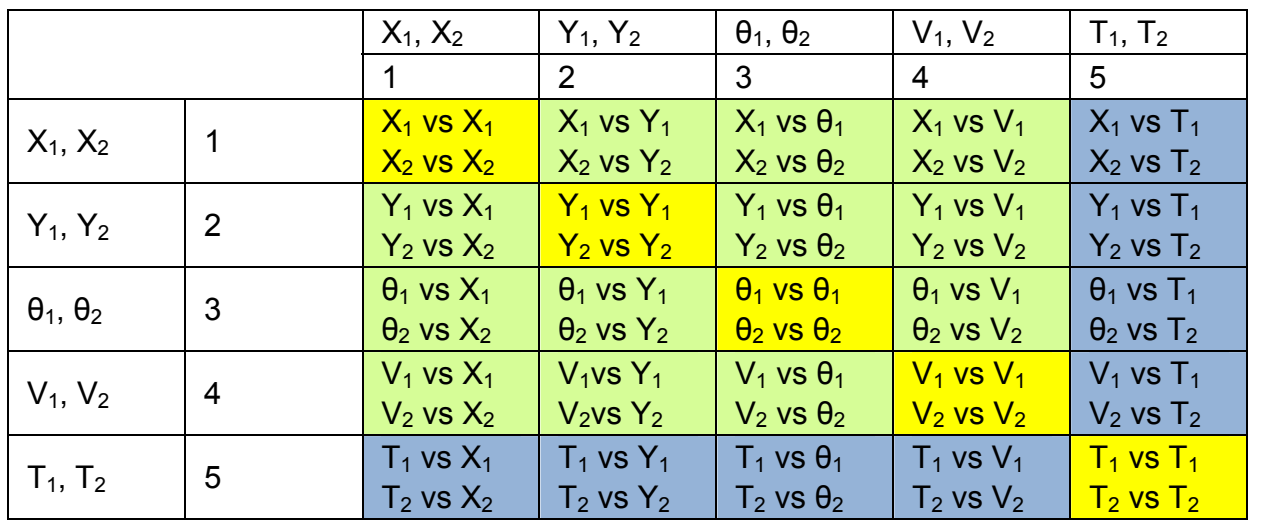

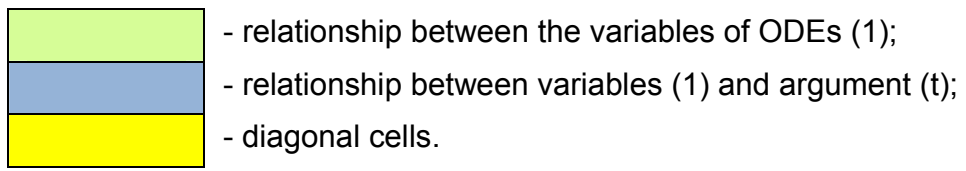

The graphs lying inside the green backgroundare the functions between the variables of ODE (1) $(x, y, \theta, v)$. The graphs located inside the blue background associate the variables with the argument TOF $(t)$. The diagonal cells-graphs placed on a light yellow background of the graphics window show the functions depending on themselves, for example, " $y$ is a function of $y$ » and so on. A small red square on each of 25 graphs shows the starting point. If we plot a horizontal and vertical line through the starting points of any graph (see Figure 5), they will connect the starting points of the graphs along the vertical row and the horizontal line.

Results analysis. Determining the magnitude of the relative error (MRE) for pistol ballistics using two different ARLsis an important element of assessment. To do this, we find the MRE of the horizontal range, the height of the trajectory, the angle of inclination of the velocity vector and the instantaneous velocity as functions of TOF. The relative error is expressed in percent. 


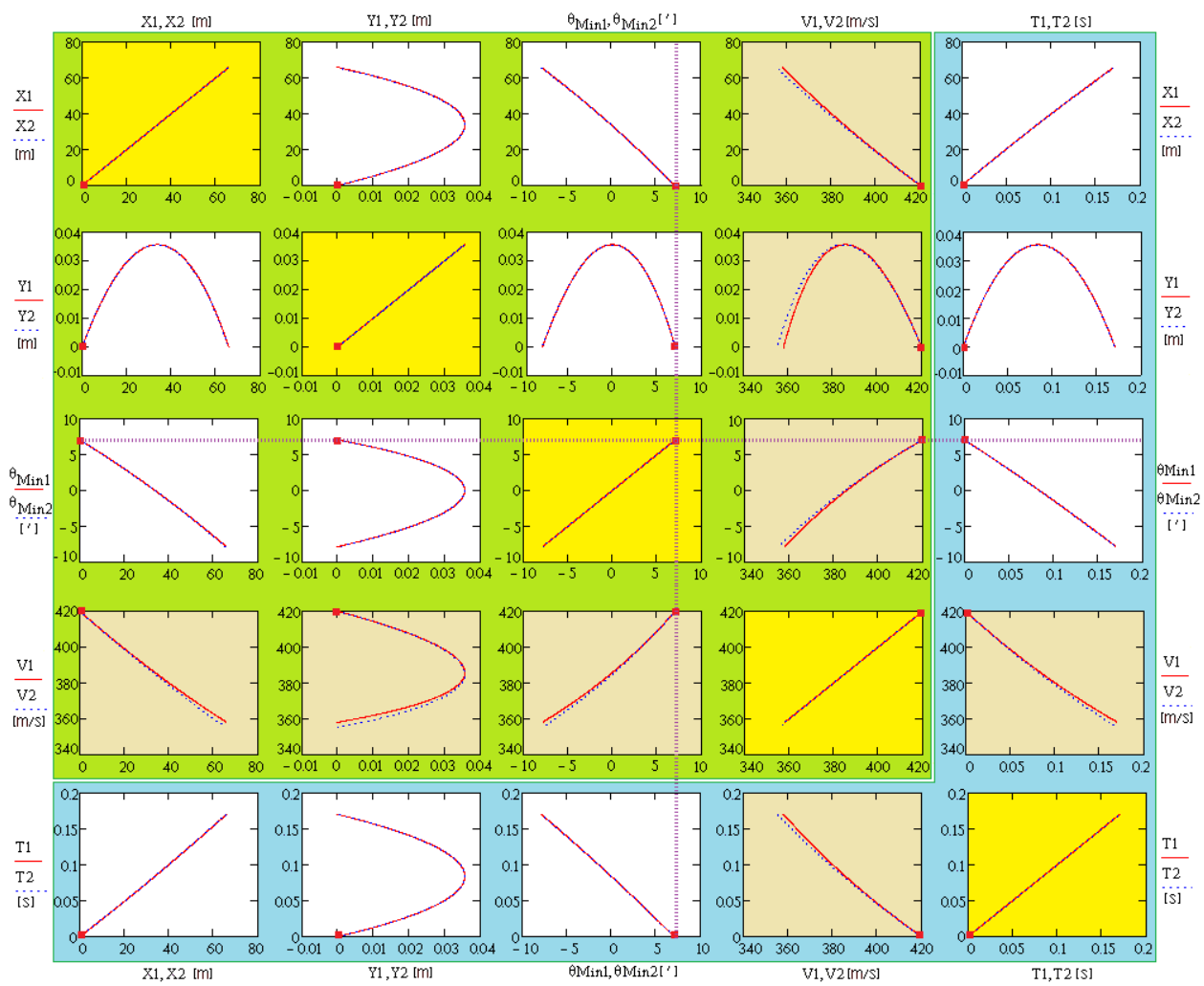

Figure 5 - Relationship between the ballistic parameters ${ }^{8}$ ODEs (1) for ARL of Siacci (blue dotted line) and 1943 year (red solid line) (in accordance with Table 4)

Puc. 5 - Соотношение между баллистическими параметрами системы (1) при законах сопротивления воздуха Сиаччи (синяя пунктирная линия) и 1943 года (красная сплошная линия) (согласно табл. 4)

Слика 5 - Однос између балистичких параметара ОДЈ (1) за Sіассі-јев закон отпора ваздуха (плава испрекидана линија) и закона из 1943. године (пуна ирвена линија) (према табели 4)

\section{Evaluation of the MRE for the horizontal range is}

$$
\delta_{x}(t)=100 \frac{\left|x(t)_{43}-x(t)_{S i}\right|}{x(t)_{43}} .
$$

8 each of 25 windows of Figure 5 contains 2 graphics, characterizing the ballistic parameters in relation to the $1943 \mathrm{ARL}$ and the Siacci ARL. 
The MRE for the height of the trajectory is

$$
\delta_{y}(t)=100 \frac{\left|y(t)_{43}-y(t)_{S i}\right|}{y(t)_{43}} .
$$

The evaluation of the MRE for the instantaneous velocity of the projectile is

$$
\delta_{v}(t)=100 \frac{\left|v(t)_{43}-v(t)_{S i}\right|}{v(t)_{43}}
$$
trajectory

The MRE for the angle of velocity vector relative to the base of a

$$
\delta_{\theta}(t)=100 \frac{\left|\theta(t)_{43}-\theta(t)_{S i}\right|}{\theta(t)_{43}} .
$$

The subscript "43» denotes that the calculations characterize the 1943 ARL and «Si» stands for Siacci.

The results of the calculations are shown in Figure 6 . The MRE is found for a TOF interval of $0-1.1 \mathrm{~s}$. The time of 1.1 seconds corresponds to the time of impact.

Figure $6 a$ gives the function MRE of the horizontal range vs TOF $\delta_{x}(t)$ and the instantaneous velocity vs TOF $\delta_{v}(t)$. The results of the calculations and comparisons show that $\delta_{x}(t)$ and $\delta_{v}(t)$ are TOFincreasing functions. The maximum MRE for $\delta_{x}(t)$ is $0.3 \%$ for TOF 1.1 seconds. A function characterizing the MRE for the instantaneous velocity $\delta_{v}(t)$ has a similar character (Figure 6a). The maximum value of this function is $0.8 \%$ (for the same TOF point).

The result of dividing the function $\delta_{v}(t)$ by the function $\delta_{x}(t)$ is shown in Figure 6b. Thus, the MRE for the instantaneous velocity is approximately 2.8-3 times larger than the MRE for the horizontal range.

In contrast to the functions mentioned above, the functions $\delta_{\theta}(t)$, $\delta_{y}(t)$ do not have an increasing character; moreover, they have discontinuities (Figures $6 \mathrm{c}, 6 \mathrm{~d}$ ). The discontinuity for the function $\delta_{\theta}(t)$ corresponds to the vertex of the trajectory. At this point, the angle $\theta$ is 
zero (division by zero). The discontinuity for the function $\delta_{y}(t)$ corresponds to the point of impact. At this point, the height of the trajectory $y$ is zero too and we have division by zero.

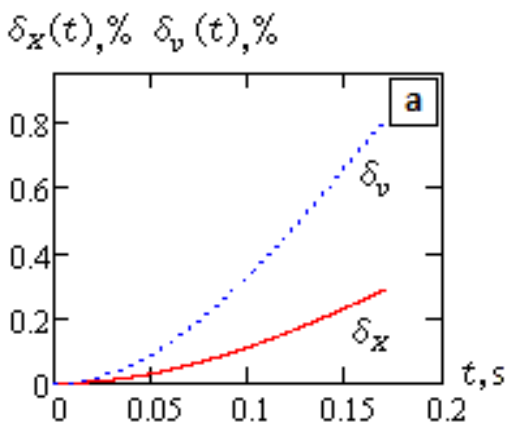

$$
\delta_{v}(t) / \delta_{X}(t)
$$

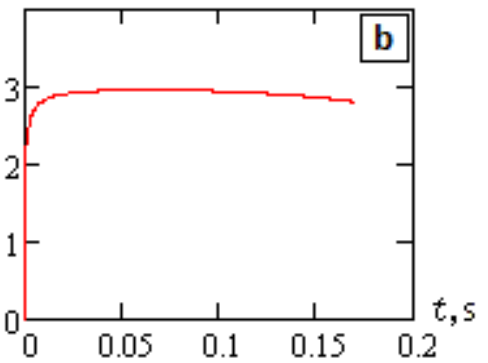

$$
\delta_{\theta}(t), \%
$$

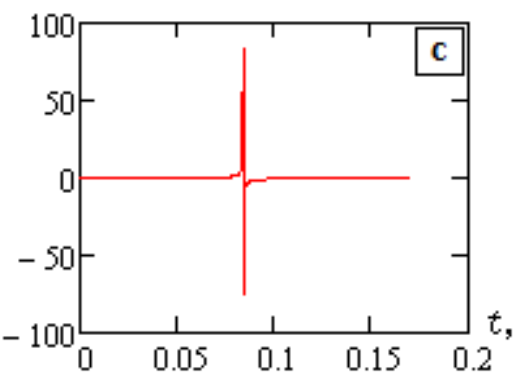

$\delta_{\mathrm{Y}}(t), \%$

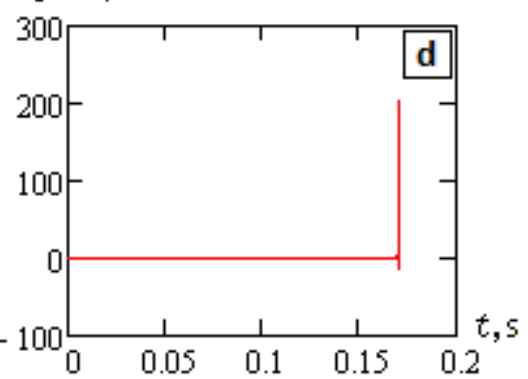

Figure 6-Results of the error analysis: $\delta_{x}(t), \delta_{v}(t), \delta_{\theta}(t), \delta_{y}(t)$

Puc. 6 - Результаты анализа погрешностей: функции $\delta_{x}(t), \delta_{v}(t), \delta_{\theta}(t), \delta_{v}(t)$

Слика 6 - Резултати анализе грешака $\delta_{x}(t), \delta_{v}(t), \delta_{\theta}(t), \delta_{y}(t)$

In contrast to the functions mentioned above, the functions $\delta_{\theta}(t)$ and $\delta_{y}(t)$ do not have an increasing character as functions $\delta_{x}(t)$ and $\delta_{v}(t)$; moreover, they have discontinuities. The discontinuity for the function $\theta(t)$ corresponds to the vertex of the trajectory $(t=0.084 \mathrm{~s})$. At this point, the $\theta(t)=0$ (division by zero). The discontinuity for the function $\delta_{y}(t)$ corresponds to the point of collision $(t=1.1 \mathrm{~s})$. At this point, the height of the trajectory is zero (division by zero). 


\section{Summary and conclusions}

The evaluations and external ballistics trajectories of the TT pistol with $7.62 \times 25 \mathrm{~mm}$ Tokarev cartridge are given for two ARLs (the 1943 year and Siacci). The characteristic of the internal-ballistic period for the TT is shown. The calculation feature is to use various forms of the ARL mathematical notation: the classical analytical formulas, the piecewise formula and the function-tables form.

For the ARL of the 1943 year, a graphical interpretation of $C_{d}(i, v)$ function in the form of a surface and its main elements is visualized. Depending on the value of the form coefficient $i$, it is demonstrated how the standard drag-function $C_{d}(v)$ is transformed.

A method of graphical comparison of the ballistic trajectory parameters is represented. This comparison takes place in a $5 \times 5$ matrix.

It is shown that due to the selection of the ballistic coefficients, it is possible to obtain sufficiently close «twins-trajectories». However, in connection with the fact that the movement of the bullet in each of them is determined by different ARLs, then the slowing down of the bullet on each of them will have its own independent nature and therefore will not coincide with the «twins-trajectories».

The computer simulation considered for the ARLs of the 1943 year and Siacci for the $7.62 \times 25$ Tokarev cartridge indicates that the profiles of the function of instantaneous projectile velocity vs time of flight had the greatest non-coincidence in relation to other ballistic parameters (e.g. horizontal range, height of the trajectory, etc.) The obtained maximum of the relative error was $0.8 \%$. Its magnitude localizes at the point of impact. The simulation results showed that the MRE for the instantaneous velocity is approximately 2.8-3 times larger than the MRE for the horizontal range. 


\section{Appendix}

Analytical form of the cubic spline function that expresses the air resistance law of the 1943 year in the Mach number range from 0.1 to 4.0

The spline function $C_{d 43_{C S}}(M)$ is given on the interval divided into 39 segments (parts). A cubic spline is a function that: on each segment there is a cubic polynomial and it has continuous first and second derivatives on the whole interval 0.1-4.0 M.Table 5 serves to describe a cubic spline $C_{d 43_{C S}}(M)$ which is defined on 39 segments. All 39 parts of the spline function have the same length equal to $0.1 \mathrm{M}$.

$$
C_{d 43_{C S}}(M)=\left(\begin{array}{cc}
f_{0}(M) & L S B_{0} \leq M \leq R S B_{0} \\
. . & . . \\
f_{i}(M) & L S B_{i} \leq M \leq R S B_{i} \\
\ddot{.} & . \cdot \\
f_{38}(M) & L S B_{38} \leq M \leq R S B_{38}
\end{array}\right),
$$

where $f_{i}(M)$ - the cubic polynomial assegments(parts) with the number $i$; $L S B_{i} ; R S B_{i}$ - the left and right segment borders; $M$ - the Mach number as an argument of $C_{d 43_{C S}}(M)$.

Each of the 39 cubic polynomials $f_{i}(M)$ has 4 coefficients. The total number of coefficients for $C_{d 43_{C S}}$ is 156 . The numbers in columns four through seven (Table 5) describe a polynomial in the form:

$$
f_{i}(M)=a_{3 i} M^{3}+a_{2 i} M^{2}+a_{1 i} M+a_{0 i},
$$

where $a_{3}, a_{2}, a_{1}, a_{0}$ - the calculated coefficients.

The spline function consisting of 39 segments and described by the coefficients from Table 5 is shown in Figure 7. All of the 39 cubic polynomials drawn in the same range of Mach numbers, i.e. in a range of $0.1-4 \mathrm{M}$, give a large number of «branches». Figure 7 and Table 5 were obtained using software (Arndt Brünner, 2018). 


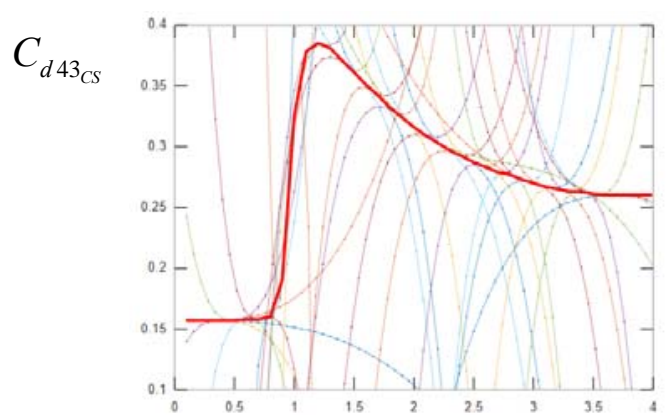

Figure 7 - Graphical construction of the Air Resistance Law of the 1943 year using 39 cubic polynomials in the MN range from 0.1 to $4 \mathrm{M}$

Puc. 7 - Графрическое конструирование закона сопротивления воздуха 1943 года с помощью 39 кубических полиномов, диапазон 0.1-4 М

Слика 7 - Закон отпора ваздуха из 1943. године, графички приказан помоћу 39 кубних полинома у опсегу од 0,1 до 4 маха

Table 5 - Interval borders and coefficients of the cubic polynomials that describe the ARL of the 1943 year

Таблица 5 - Границы интервалов и коэфффициенты, описывающие закон сопротивления воздуха 1943 года

Табела 5 - Границе и коефицијенти интервала кубних полинома који описују закон отпора ваздуха из 1943. године

\begin{tabular}{|l|l|l|l|l|l|l|}
\hline \multirow{2}{*}{$\begin{array}{l}\text { Num- } \\
\text { ber }\end{array}$} & \multicolumn{3}{|l|}{ Borders } & \multicolumn{4}{l|}{ Coefficients of the cubic polynomials with the argument $M$} \\
\cline { 2 - 7 } & Left & Right & $\mathrm{M}^{\wedge} 3$ & $\mathrm{M}^{\wedge} 2$ & $\mathrm{M}^{\wedge} 1$ & $\mathrm{M}^{\wedge} 0$ \\
\hline 1 & 2 & 3 & 4 & 5 & 6 & 7 \\
\hline 1 & 0.1 & 0.2 & -0.00779 & 0.002337 & -0.000156 & 0.157 \\
\hline 2 & 0.2 & 0.3 & 0.038952 & -0.025708 & 0.005453 & 0.156626 \\
\hline 3 & 0.3 & 0.4 & -0.148018 & 0.142565 & -0.045029 & 0.161674 \\
\hline 4 & 0.4 & 0.5 & 0.553119 & -0.6988 & 0.291517 & 0.116801 \\
\hline 5 & 0.5 & 0.6 & -1.064459 & 1.727567 & -0.921666 & 0.318999 \\
\hline 6 & 0.6 & 0.7 & 1.704716 & -3.256948 & 2.069043 & -0.279143 \\
\hline 7 & 0.7 & 0.8 & -2.754406 & 6.10721 & -4.485868 & 1.250336 \\
\hline 8 & 0.8 & 0.9 & 35.312909 & -85.254348 & 68.603379 & -18.24013 \\
\hline 9 & 0.9 & 1.0 & -61.497231 & 176.13303 & -166.645262 & 52.334463 \\
\hline 10 & 1.0 & 1.1 & 23.676014 & -79.386704 & 88.874473 & -32.838782 \\
\hline 11 & 1.1 & 1.2 & 2.793175 & -10.473335 & 13.069766 & -5.043723 \\
\hline 12 & 1.2 & 1.3 & 0.151287 & -0.962537 & 1.656809 & -0.478541 \\
\hline 13 & 1.3 & 1.4 & 1.601679 & -6.619067 & 9.010297 & -3.665052 \\
\hline 14 & 1.4 & 1.5 & -0.558002 & 2.451591 & -3.688623 & 2.261111 \\
\hline 15 & 1.5 & 1.6 & 0.630327 & -2.89589 & 4.332598 & -1.7495 \\
\hline
\end{tabular}




\begin{tabular}{|c|c|c|c|c|c|c|}
\hline \multirow{2}{*}{$\begin{array}{l}\text { Num- } \\
\text { ber }\end{array}$} & \multicolumn{2}{|c|}{ Borders } & \multicolumn{4}{|c|}{ Coefficients of the cubic polynomials with the argument $M$} \\
\hline & Left & Right & $M^{\wedge} 3$ & $\mathrm{M}^{\wedge} 2$ & $M^{\wedge} 1$ & $M^{\wedge} 0$ \\
\hline 16 & 1.6 & 1.7 & -0.963308 & 4.753562 & -7.906526 & 4.778033 \\
\hline 17 & 1.7 & 1.8 & 1.222906 & -6.396132 & 11.047955 & -5.96284 \\
\hline 18 & 1.8 & 1.9 & -0.928316 & 5.22047 & -9.861929 & 6.583091 \\
\hline 19 & 1.9 & 2.0 & 0.49036 & -2.865984 & 5.502333 & -3.147608 \\
\hline 20 & 2.0 & 2.1 & -0.033122 & 0.274906 & -0.779447 & 1.040245 \\
\hline 21 & 2.1 & 2.2 & -0.357871 & 2.320827 & -5.075881 & 4.047749 \\
\hline 22 & 2.2 & 2.3 & 0.464608 & -3.107534 & 6.866514 & -4.710007 \\
\hline 23 & 2.3 & 2.4 & -0.500559 & 3.552115 & -8.450678 & 7.033173 \\
\hline 24 & 2.4 & 2.5 & 0.537628 & -3.922831 & 9.489192 & -7.318723 \\
\hline 25 & 2.5 & 2.6 & -0.649953 & 4.984029 & -12.777958 & 11.237235 \\
\hline 26 & 2.6 & 2.7 & 1.062185 & -8.370651 & 21.94421 & -18.85531 \\
\hline 27 & 2.7 & 2.8 & -1.598787 & 13.183226 & -36.251257 & 33.52061 \\
\hline 28 & 2.8 & 2.9 & 1.332964 & -11.443485 & 32.703532 & -30.837193 \\
\hline 29 & 2.9 & 3.0 & -0.733069 & 6.530999 & -19.42247 & 19.551276 \\
\hline 30 & 3.0 & 3.1 & 0.59931 & -5.460413 & 16.551765 & -16.42296 \\
\hline 31 & 3.1 & 3.2 & -0.664173 & 6.289986 & -19.874472 & 21.217485 \\
\hline 32 & 3.2 & 3.3 & 1.057383 & -10.236952 & 33.011728 & -35.194462 \\
\hline 33 & 3.3 & 3.4 & -1.565357 & 15.728176 & -52.673194 & 59.058953 \\
\hline 34 & 3.4 & 3.5 & 1.204047 & -12.519753 & 43.369764 & -49.789733 \\
\hline 35 & 3.5 & 3.6 & -0.250832 & 2.756477 & -10.097038 & 12.588203 \\
\hline 36 & 3.6 & 3.7 & -0.200721 & 2.215277 & -8.148718 & 10.250219 \\
\hline 37 & 3.7 & 3.8 & 0.053714 & -0.608947 & 2.300908 & -2.637653 \\
\hline 38 & 3.8 & 3.9 & -0.014135 & 0.164534 & -0.63832 & 1.085369 \\
\hline 39 & 3.9 & 4.0 & 0.002827 & -0.033925 & 0.13567 & 0.079182 \\
\hline
\end{tabular}

The Internet online service (Arndt Brünner, 2018) can be used for cubic spline calculation and spline function visualization.

\section{References}

-Arndt Brünner. 2018. Rechner für kubische Splines. [Internet]. Available at: http://www.arndt-bruenner.de/mathe/scripts/kubspline1.htm (in German). Accessed: 07.03.2018.

Bogdanovich, B. 2012. Yugoslavskiy TT po imeni "Tetejats". Oruzhiye, 10 (oktyabr'), pp.42-56 (in Russian). (In the original: Богданович, Б. 2012. Югославский ТТ по имени "Тетејац". Оружие. 10 (октябрь). С. 42-56).

Faraponov, V.V., Bimatov, V.I., Savkina, N.V., \& Khristenko, Yu.F. 2017. Praktikum po aeroballistike. Tomsk: STT Publishing (in Russian). (In the original: Фарапонов, В.В., Биматов, В.И., Савкина, Н.В., Христенко, Ю.Ф. 2017. Практикум по аэробаллистике. Томск: STT Publishing). 
http://ballistics.eu/index.html. Accessed: 07.03.2018.

https://forum.guns.ru/forummessage/91/492765.html (in Russian). Accessed: 07.03.2018.

http://popgun.ru/viewtopic.php?f=159\&t=213919\&start=10 (in Russian). Accessed: 07.03.2018.

Jankových, R. 2012. Přechodová a vnější balistika. [Internet]. Available at: http://www.fsiforum.cz/upload/soubory/databaze-

predmetu/0HZ/10\%20Hlavňové\%20zbraně\%20Přechodová\%20a\%20vněǰ̌ $\% 20$ balistika.pdf (in Czech). Accessed: 07.03.2018.

Khaikov, V. 2017. Review of mathematical formulas for the air resistance law of the 1943 year. Part 1. Electronic Information Systems, 4(15), pp.74-90 (in Russian). (In the original: Хайков, В. 2017. Обзор аналитических выражений закона сопротивления воздуха 1943 г. Часть 1. Электронные информационные системы 4(15). С. 74-90).

Khaikov, V. 2018. Mathematical modeling and computer simulation of the tube artillery external ballistics basic problem by means of the Mathcad software. Vojnotehnički glasnik / Military Technical Courier, 66(2), pp.281-303. Available at: https://doi.org/10.5937/vojtehg66-15328.

Kirillov, V.M. 1963. Osnovaniya ustroystva i proyektirovaniya strelkovogo oruzhiya. Penza: Penzenskoye Vyssheye Artilleriyskoye Inzhenernoye Uchilishche (in Russian). (In the original: Кириллов, В.М. 1963. Основания устройства и проектирования стрелкового оружия. Пенза: Пензенское Высшее Артиллерийское Инженерное Училище).

Kir'yanov, D.V. 2012. Mathcad 15/Mathcad Prime 1.0. Sankt-Peterburg: BKhV (in Russian). (In the original: Кирьянов, Д.В. 2012. Mathcad 15/Mathcad Prime 1.0. Санкт-Петербург: БХВ).

Konovalov, A.A., \& Nikolayev, Yu.V. 1979. Vneshnyaya ballistika. Moscow: Tsentral'nyy Nauchno-Issledovatel'skiy Institut Informatsii (in Russian). (In the original: Коновалов, А.А., Николаев, Ю.В. 1979. Внешняя баллистика. Москва: Центральный Научно-Исследовательский Институт Информации).

Kozlitin, I.A., \& Omelyanov, A.S. 2016. A method for smooth approximation of drag functions. Mathematical Models and Computer Simulations, 28(10), pp.23-32 (in Russian). (In the original: Козлитин, И.А., Омельянов, А.С. 2016. Метод построения гладкой аппроксимации законов сопротивления. Математическое моделирование, 28(10). С. 23-32).

Mori, E. 2013. Balistica Pratica. IImiolibro Self Publishing (in Italian). Serbian).

Regodić, D. 2006. Spoljna balistika. Belgrade: Vojna akademija (in

Semikolenov, N.P., Bondarenko, F.G., \& Krasner, N.Y. 1971. Principles of small unit weapons firing. Charlottesville, US: Army Foreign Science and Technology Center. Trans. from Russian.

Shapiro, Ya.M. 1946. Vneshnyaya ballistika. Moscow: Gosudarstvennoye izdatel'stvo oboronnoy promyshlennosti (in Russian). (In the original: Шапиро, Я.М. 1946. Внешняя баллистика. Москва: Государственное издательство оборонной промышленности). 
Vodorezov, Yu.G. 2017. Teoriya i praktika strel'by iz nareznogo dlinnostvol'nogo strelkovogo oruzhiya. Chast' 1. Moscow: Moskovskiy Gosudarstvennyy Tekhnicheskiy Universitet (in Russian). (In the original: Водорезов, Ю.Г. 2017. Теория и практика стрельбы из нарезного длинноствольного стрелкового оружия. Часть 1.).

КОМПЬЮТЕРНОЕ МОДЕЛИРОВАНИЕ ВНЕШНЕЙ БАЛЛИСТИКИ

ПИСТОЛЕТА С ИСПОЛЬЗОВАНИЕМ ДВУХ РАЗЛИЧНЫХ

ЗАКОНОВ СОПРОТИВЛЕНИЯ ВОЗДУХА (рассмотренИе на примере пистолета 7.62 мм ТТ)

Вадим Л. Хайков,

независимый исследователь, г. Краснодар, Российская Федерация

ОБЛАСТЬ: механика - баллистика

ВИД СТАТЬИ: оригинальная научная статья

ЯЗЫК СТАТЬИ: английский

Резюме:

Для пистолетов М54, M57 (7.62×25 Токарев патрон) собраны баллистические параметры характеризующие их баллистику. В статье дан расчёт внешнебаллистических траекторий для двух законов сопротивления воздуха: 1943 года и Сиаччи, при этом использованы разные виды их математической записи (классические аналитические формулы, фформулы кусочного вида, а также фрункци-таблицы). Для решения баллистической системы дифрференциальных уравнений при табличном задании фрункции сопротивления воздуха используются сплайны. Для закона 1943 года показана графическая интерпретация фрункции $C_{d}(i, v)$ в виде поверхности и её основные элементы. Показано, что такую поверхность можно построить для любого закона сопротивления воздуха. Показан способ графического сравнения баллистических траекторных параметров. Все вычисления выполнены в среде Mathcad 15, в статье приведён программный код расчёта. Показано, что за счёт подбора баллистических коэффрициентов можно получить достаточно близкие по форме траектории. Однако в связи с тем, что движение пули по каждой из них определяется разными законами сопротивления воздуха, то замедление пули на каждой из них будет иметь свою собственную независимую форму и поэтому может не совпадать с «траекторией-двойником».

Ключевые слова: внешняя баллистика, пистолет M54, пистолет М57, патрон 7.62×25 TT, закон сопротивления воздуха, траектория пули, сплайн, Mathcad. 
КОМПЈУТЕРСКА СИМУЛАЦИЈА СПОЉНЕ БАЛИСТИКЕ ПИШТОЉА ПРИМЕНОМ ДВА РАЗЛИЧИТА ЗАКОНА ОТПОРА ВАЗДУХА (на примеру пиштоља 7.62 мм ТТ)

Вадим Л. Хајков

независни истраживач, Краснодар, Руска Федерација

ОБЛАСТ: механика - балистика

ВРСТА ЧЛАНКА: оригинални научни чланак

ЈЕЗИК ЧЛАНКА: енглескИ

Сажетак:

За балистику метка пиштоља (пушке) карактеристична су два балистичка коефицијента која се односе на различите законе отпора ваздуха. Колико су сличне балистичке путање добијене помоћу различитих закона и какве су разлике између њих? У овом раду процењује се спољна балистичка путања на основу два закона оптора ваздуха (закон из 1943. године и Siacci-jeв закон). Сви добијени резултати односе се на пиштољ ТT са метком „токарев” калибра 7.62×25 мм. У раду је, такође, приказан начин израчунавања балистичке путање ако је закон отпора ваздуха изражен као рационална фрункција, прекидна фуннкција или spline. Закон оптора ваздуха из 1943. године приказан је као граффичка интерпретација фрункције $C d(i, v)$ у облику површине. Показано је да је могуће добити довољно сличан облик балистичких путања захваљујући избору балистичких коефицијената. Представљен је метод графичког поређења спољних балистичких параметара, као и математички алати за квантитативну анализу облика балистичких кривих. Предложено је да се разлика између две путање одреди помоћу релативне грешке у односу на изабрани балистички параметар. Компјутерска симулација два поменута закона отпора ваздуха за зрно „токарев” калибра 7.62×25 мм показује да су профрили фрункције односа тренутне брзине пројектила и времена лета имали највеће неподударање у односу на остале балистичке параметре (нпр. хоризонтални домет, висину путање, итд.). Највећа добијена вредност релативне грешке била је 0,8\%, локализована у тачки удара.

Кључне речи: компјутерска симулација, спољна балистика, поштољ TT, закон отпора ваздуха, фрункција чеоног отпора, закон из 1943. године, путања зрна, spline, Mathcad 
Paper received on / Дата получения работы / Датум пријема чланка: 12.02.2018. Manuscript corrections submitted on / Дата получения исправленной версии работы / Датум достављања исправки рукописа: 12.04.2018.

Paper accepted for publishingon / Дата окончательного согласования работы / Датум коначног прихватања чланка за објављивање: 14.04.2018.

(c) 2018 The Author. Published by Vojnotehnički glasnik / Military Technical Courier

(www.vtg.mod.gov.rs, втг.мо.упр.срб). This article is an open access article distributed under the terms and conditions of the Creative Commons Attribution license (http://creativecommons.org/licenses/by/3.0/rs/).

() 2018 Автор. Опубликовано в «Военно-технический вестник / Vojnotehnički glasnik / Military Technical Courier» (www.vtg.mod.gov.rs, втг.мо.упр.срб). Данная статья в открытом доступе и распространяется в соответствии с лицензией «Creative Commons» (http://creativecommons.org/licenses/by/3.0/rs/).

( 2018 Аутор. Објавио Војнотехнички гласник / Vojnotehnički glasnik / Military Technical Courier (www.vtg.mod.gov.rs, втг.мо.упр.срб). Ово је чланак отвореног приступа и дистрибуира се у складу са Creative Commons licencom (http://creativecommons.org/licenses/by/3.0/rs/). 